Jurnal Logistik Bisnis, Vol. 10, No.2, November 2020

ISSN : 2086-8561

\title{
ANALISIS MANAJEMEN RISIKO DAN STRATEGI PENANGANAN RISIKO PADA PT AGILITY INTERNATIONAL MENGGUNAKAN METODE HOUSE OF RISK (HOR)
}

\author{
Achmad Andriyanto,ST.,MT.1), Nur Khafifah Mustamin.2). \\ ${ }_{1}$ D3 Administrasi Logistik, Politeknik Pos Indonesia \\ email: achmadandriyanto@poltekpos.ac.id \\ ${ }_{2}$ D3 Administrasi Logistik, Politeknik Pos Indonesia \\ email: nurkhafifah1211@gmail.com
}

\begin{abstract}
Abstrak
PT Agility International merupakan salah satu perusahaan multinational yang telah cukup lama berkembang, khususnya di Indonesia. PT Agility International bergerak di bidang penyedia jasa logistik dan freight forwarding. Tapi dalam prosesnya terjadi permasalahan di PT Agility International yaitu keterlambatan pengiriman atau shipment. Keterlambatan pengiriman terjadi karena terlambatnya dalam melakukan proses stuffing yang ditimbulkan oleh beberapa kejadian risiko. Untuk mengurangi dan mengatasi beberapa risiko yang terjadi, maka digunakanlah metode House of Risk (HOR). Metode ini bertujuan untuk meminimalisir risiko yang dapat menyebabkan terjadinya permasalahan dalam proses ekspor di PT Agility International. HOR terbagi menjadi 2 fase dimana fase 1 merupakan sebuah fase untuk mengidentifikasi kejadian dan agen risiko, sedangkan fase 2 merupakan sebuah fase untuk merancang strategi mitigasi yang dilakukan dalam penanganan agen risiko yang efektif untuk diterapkan di PT Agility International. Hasil perhitungan berdasarkan pengamatan penulis serta penyebaran kuisioner dari 6 responden teridentifikasi 17 kejadian risiko yang disebabkan oleh 19 agen penyebab risiko, 8 agen risiko yang termasuk dalam kategori prioritas dan 11 lainnya termasuk dalam kategori non prioritas. Agen risiko yang memiliki indeks prioritas tertinggi yaitu pengurusan dokumen ke pihak shipping line yang terlambat (A10) dengan indeks prioritas sebesar 1.296 serta strategi penanganan dari agen penyebab risiko yang timbul berjumlah 11, dimana strategi penanganan yang tertinggi yaitu membuat checklist harian secara rutin (PA3) dengan nilai ETD 4.009,50.
\end{abstract}

Kata Kunci: Metode House of Risk, Risk Events dan Risk Agents, Strategi Penanganan. 


\section{PENDAHULUAN}

Berkembangnya persaingan bisnis, membuat perdagangan juga semakin berkembang sehingga memasuki pasar internasional, inilah yang disebut dengan perdagangan internasional. Dengan adanya perdagangan internasional membuat perusahaan logistik memiliki peran yang sangat penting dalam menjalankan kegiatan perdagangan internasional serta memiliki peran terhadap perkembangan bisnis, khususnya yang ada di Indonesia. Dengan meningkatnya juga persaingan bisnis di bidang logistik di Indonesia, membuat perusahaan logistik telah banyak didirikan di Indonesia baik bergerak di bidang warehousing, freight forwarding, shipping line dan lain-lainnya. Salah satu perusahaan yang sudah cukup lama didirikan di Indonesia dan merupakan salah satu perusahaan logistik internasional yaitu PT Agility International. Perkembangan PT Agility International di berbagai negara, tentu saja didukung oleh banyaknya customer yang telah mempercayakan segala keperluan dan kebutuhan pengiriman kepada PT Agility International. PT Agility International memiliki banyak pelanggan yang telah memberikan kepercayaan dalam menangani kegiatan logistik khususnya ekspor impor. Permasalahan yang diangkat mengenai keterlambatan stuffing sehingga mengakibatkan keterlambatan dalam pengiriman atau shipment menjadi diundur. Berikut tabel presentase keterlambatan stuffing pada bulan Februari - April 2020 :

Tabel 1 Persentase Keterlambatan Stuffing Bulan Februari - April 2020

\begin{tabular}{|c|c|c|c|}
\hline Bulan & $\begin{array}{c}\text { Total } \\
\text { Shipment } \\
\text { Terlambat }\end{array}$ & $\begin{array}{c}\text { Total stuffing } \\
\text { yang terlambat }\end{array}$ & Presentase (\%) \\
\hline Februari & 60 & 12 & $20 \%$ \\
\hline Maret & 35 & 17 & $48 \%$ \\
\hline April & 37 & 9 & $24 \%$ \\
\hline
\end{tabular}

Tabel 1 menjelaskan bahwa adanya permasalahan yang terjadi dalam proses atau kegiatan ekspor dan menimbulkan keterlambatan dalam pengirimannya. Maka dari itu, perlu diketahui setiap permasalahan dari setiap risiko yang mungkin timbul dari permasalahan yang ada di perusahaan agar tidak terjadi lagi keterlambatan dalam proses stuffing yang akan berdampak pada keterlambatan pengiriman.

Berdasarkan uraian dari latar belakang masalah, maka penulis merumuskan permasalahan yang akan dibahas dalam penelitian adalah sebagai berikut :

1. Apa saja kejadian risiko sehingga mengakibatkan keterlambatan atau kemunduran dalam proses stuffing dan keterlambatan dalam pengiriman khususnya ekspor pada PT Agility International?

2. Apa saja agen risiko yang berpengaruh dalam keterlambatan atau kemunduran dalam proses stuffing dan keterlambatan dalam pengiriman khususnya ekspor pada PT Agility International?

3. Bagaimana strategi penanganan yang dapat dilakukan PT Agility International dalam menangani risiko yang memiliki kategori prioritas?

\section{METODE PENELITIAN}

Metode rancangan penelitian kegiatan yang dilakukan peneliti untuk menjawab pertanyaan penelitian sebagai berikut :

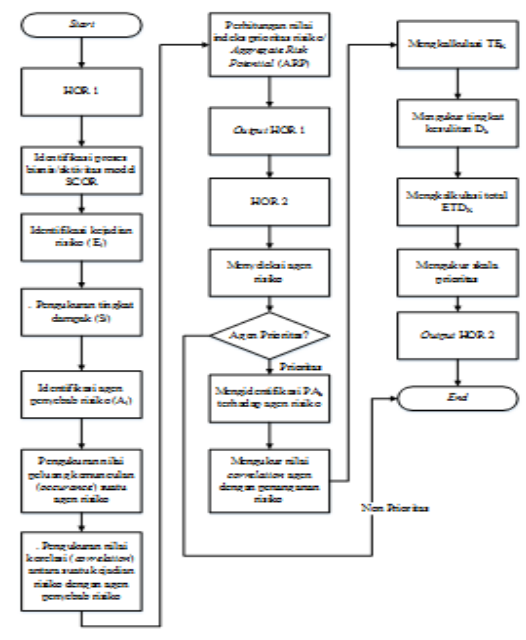

Gambar 1 Flowchart Metode HOR

Penjelasan flowchart metode pada penelitian, menggunakan metode HOR dimana metode HOR dibagi dalam 2 model yaitu HOR 1 dan HOR 2 sebagai berikut :

1. Identifikasi proses bisnis /aktivitas model SCOR dengan menjadi beberapa proses yaitu plan, source, make, deliver dan return.

2. Identifikasi kejadian risiko dimana risiko tersebut menjabarkan semua kejadian yang kemungkinan akan timbul dan mengakibatkan kerugian pada perusahaan.

3. Identifikasi pengukuran tingkat dampak $\left(S_{i}\right)$ dimana nilai yang dihasilkan mengetahui seberapa besar gangguan yang ditimbul dari $\left(E_{i}\right)$. Untuk mencari $\left(S_{i}\right)$ sebagai berikut :

Keterangan:

$$
S_{i}=\sqrt[k]{S_{i 1} \times S_{i 2} \times \ldots \times S_{i k}}
$$

$S_{i}=$ Tingkat dampak suatu risiko (Severity level of risk)

$i=1,2, \ldots . \mathrm{n}$;

$k=$ penilaian orang $\mathrm{ke}-\mathrm{k}$ 
4. Identifikasi agen penyebab risiko dimana bertujuan untuk mengetahui faktor apa saja yang dapat menyebabkan terjadinya suatu kejadian risiko.

5. Mengukur nilai occurance atau nilai peluang kemunculan suatu agen risiko. Untuk mencari occurance level risk sebagai berikut :

$$
O_{j}=\sqrt[k]{O_{j 1} x O_{j 2} \times \ldots \ldots \times O_{j k}} \quad \forall \mathrm{j} ; \text { dimana } \mathrm{j}=
$$

Keterangan :

$O_{j}=$ Tingkat kemunculan risiko (occurance level risk)

$k=$ penilaian orang $\mathrm{ke}-\mathrm{k}$

6. Mencari nilai korelasi antara kejadi risiko dengan agen penyebab risiko dimana nilai korelasi yang dihasilkan terdiri atas $0,1,3,9$ dimana dimana 0 menunjukkan tidak ada hubungan korelasi, 1 menggambarkan hubungan korelasi kecil, 3 menggambarkan korelasi sedang dan 9 menggambarkan korelasi tinggi.

7. Perhitungan nilai ARP yang akan digunakan sebagai bahan pertimabangan untuk menentukan prioritas penanganan risiko yang akan menajdi input dalam HOR 2 nantinya. Berikut perhitungan nilai ARP :

$$
A R P_{j}=O_{j} \sum S_{i} R_{i j}
$$

Keterangan :

$A R P_{j}=$ Aggregate Risk Potential (risk priority

index)

$O_{j} \quad=$ Tingkat kemunculan risiko (occurance

level of risk)

$S_{i} \quad=$ Tingkat dampak suatu risiko (severity

level of risk)

$R_{i j} \quad=$ Korelasi antara agen risiko dengan

risiko

8. Output HOR 1 yang akan digunakan sebagai input dalam HOR 2.

9. Untuk HOR 2 tahap awal dimulai dengan menyeleksi agen risiko dari nilai ARP tertinggi hingga terendah menggunakan analisa pareto.

10. Jika agen risiko termasuk kategori prioritas maka langkah selanjutnya mengidentifikasi aksi mitigasi yang relevan $\left(P A_{k}\right)$ terhadap agen risiko. Jika agen risiko bukan merupakan agen prioritas maka agen tersebut tidak diproses lebih lanjut dan selesai.

11. Mengukur nilai correlation agen dengan penanganan risiko dimana nilai korelasi

12. Mengkalkulasi $\left(T E_{k}\right)$ dengan formula sebagai berikut :

$$
T E_{k}=\sum A R P_{j} E_{j k}
$$

Keterangan :

$T E_{k}=$ Total efektivitas

$A R P j=$ Prioritas risiko (risk priority index)

Ejk = Nilai korelasi antara suatu agen risiko dengan penanganan risiko

13. Mengukur tingkat kesulitan dalam penerapan aksi mitigasi $\left(D_{k}\right)$ untuk mereduksi kemunculan agen risiko

14. Mengkalkulasi total $\left(E T D_{k}\right)$ dengan rumus sebagai berikut :

$$
E T D_{k}=\frac{T E_{k}}{D_{k}}
$$

Keterangan :

$E T D_{k}=$ Effectiveness to difficulty of ratio

$T E_{k} \quad=$ Total efektivitas

$D_{k}=$ Tingkat kesulitan dalam melakukan upaya pencegahan untuk diterapkan di perusahaan

15. Mengukur skala prioritas dimana nilai prioritas utama diberikan kepada aksi mitigasi yang memiliki nilai ETD tertinggi.

16. Output HOR fase 2.

\section{HASIL DAN PEMBAHASAN}

\begin{tabular}{|c|c|c|c|c|}
\hline No. & $\begin{array}{c}\text { Major } \\
\text { processes }\end{array}$ & $\begin{array}{c}\text { Sub } \\
\text { processes }\end{array}$ & Risk Events & Keterangan \\
\hline 1. & Pian & $\begin{array}{l}\text { Shipment } \\
\text { elspor }\end{array}$ & $\begin{array}{l}\text { 1. Pentboham jadval } \\
\text { untuk kegiatan atan } \\
\text { proses stuffing } \\
\text { 2. Sistem IT mengaimi } \\
\text { trouble }\end{array}$ & $\begin{array}{l}\text { 1. Bizki } \\
\text { Hutomo (Sea } \\
\text { freight } \\
\text { export) } \\
\text { 2. Aris } \\
\text { Arasyidive } \\
\text { (Booking } \\
\text { teawn) }\end{array}$ \\
\hline 2. & Make & $\begin{array}{l}\text { Proses } \\
\text { booking } \\
\text { space dan } \\
\text { kepistan } \\
\text { stuffing }\end{array}$ & 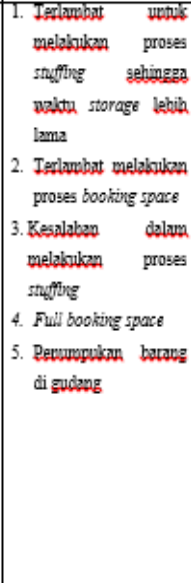 & 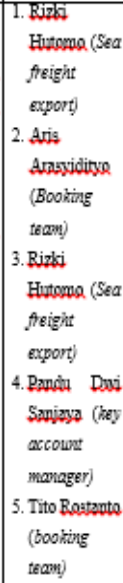 \\
\hline
\end{tabular}

\subsection{House of Risk 1}

1. Identifikasi Proses Bisnis

Tabel 2 Identifikasi Proses Bisnis Model SCOR 


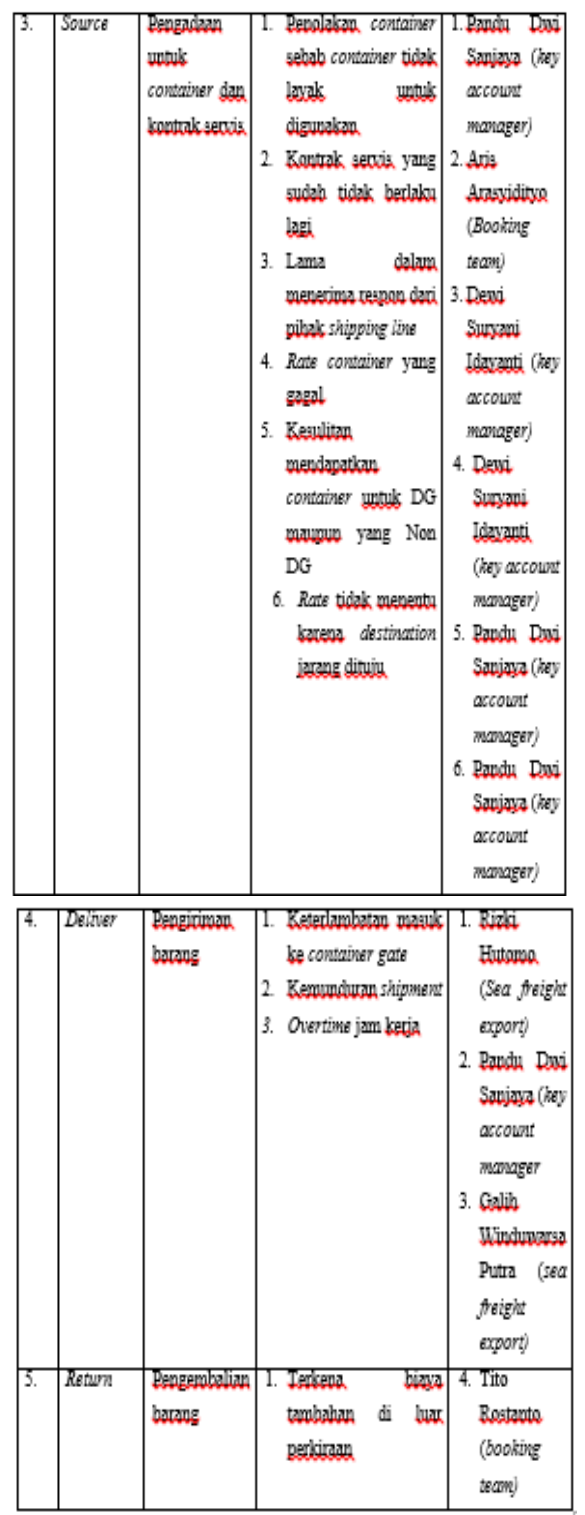

2. Identifikasi Kejadian Risiko

Tabel 3 Hasil Identifikasi Kejadian Risiko

\begin{tabular}{|c|c|c|c|c|c|c|c|c|}
\hline Kade & Kejadian Eisilso & 1 & & $\frac{e s p}{3}$ & & 5 & & Severing \\
\hline E1 & 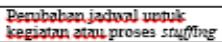 & 4 & 6 & 7 & 5 & 6 & 6 & 6 \\
\hline E2 & 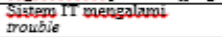 & 3 & 4 & 4 & 6 & 5 & 7 & 5 \\
\hline E3 & 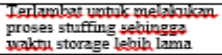 & 4 & 4 & 8 & 6 & 5 & 3 & 5 \\
\hline E4 & $\begin{array}{l}\text { Ierlambart yelastrulkan } \\
\text { proses booking space }\end{array}$ & 7 & 7 & 7 & 6 & 7 & 8 & 7 \\
\hline E5 & 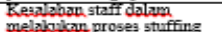 & 8 & 6 & 6 & 5 & 6 & 6 & 6 \\
\hline E6 & Full booking space & 5 & 6 & 6 & 6 & 8 & 7 & 6 \\
\hline E7 & 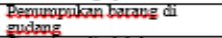 & 4 & 3 & 7 & 6 & 4 & 6 & 5 \\
\hline E8 & 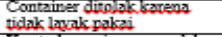 & 8 & 6 & 9 & 7 & 8 & 9 & 8 \\
\hline E9 & $\begin{array}{l}\text { Kaytrok seccis yang sudah } \\
\text { tidak berlakn lagi }\end{array}$ & 7 & 7 & 7 & 8 & 9 & 8 & 8 \\
\hline E10 & $\begin{array}{l}\text { Lama dalam meneripons } \\
\text { reapen dari pibsk shipping } \\
\text { line }\end{array}$ & 5 & 7 & 6 & 8 & 8 & 8 & 7 \\
\hline E11 & Rate cobtainer yang gogal & 6 & 7 & 7 & 5 & 6 & 4 & 6 \\
\hline E12 & Keaplitan mendapetion & 5 & 5 & 7 & 6 & 7 & 9 & 6 \\
\hline E13 & 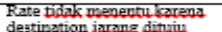 & 5 & 7 & 6 & 4 & 3 & 4 & 5 \\
\hline E14 & 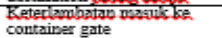 & 6 & 6 & 8 & 7 & 5 & 6 & 6 \\
\hline E15 & 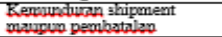 & 4 & 5 & 7 & 6 & 3 & 5 & 5 \\
\hline E16 & Overtime jem keda & 3 & 5 & 4 & 4 & 6 & 4 & 4 \\
\hline E17 & Terkena bixys tambothandi & 4 & 5 & 5 & 7 & 8 & 6 & 6 \\
\hline
\end{tabular}

3. Pengukuran Tingkat Dampak

Berikut merupakan salah satu contoh perhitungan yang dipilih secara acak pada setiap kejadian risiko sebagai berikut:

$$
\begin{aligned}
S_{1} & =\sqrt[6]{4 \times 6 \times 7 \times 5 \times 6 \times 6} \\
& =\sqrt[6]{30,240}=5.5 \approx 6 \\
S_{10} & =\sqrt[6]{5 \times 7 \times 6 \times 8 \times 8 \times 8} \\
& =\sqrt[6]{107,520}=6.8 \approx 7 \\
S_{17} & =\sqrt[6]{4 \times 5 \times 5 \times 7 \times 8 \times 6} \\
& =\sqrt[6]{33,600}=5.6 \approx 6
\end{aligned}
$$

\begin{tabular}{|c|c|c|c|}
\hline Kade & Kejadian Risilso & $\begin{array}{c}\text { Trhapan } \\
\text { SCOR }\end{array}$ & $\begin{array}{l}\text { Tingkat } \\
\text { Dempal; }\end{array}$ \\
\hline$E_{1}$ & 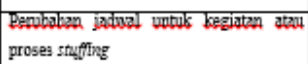 & Pian & 6 \\
\hline $\mathrm{E}_{2}$ & Sistem IT mengallawi trowble & Pian & 5 \\
\hline$E_{2}$ & 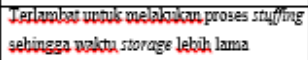 & 16.28 & 5 \\
\hline$E_{4}$ & $\begin{array}{l}\text { Ierlambat melakukat proses booking } \\
\text { space }\end{array}$ & Thave & 7 \\
\hline $\mathrm{E}_{3}$ & 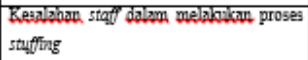 & thais & 6 \\
\hline$E_{6}$ & Ful booking space & 16:8 & 6 \\
\hline E, & 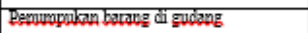 & परris & 5 \\
\hline$E_{s}$ & Container difolak bareps ticak lasalk palkai & Sowce & 8 \\
\hline $\mathrm{E}_{\text {? }}$ & 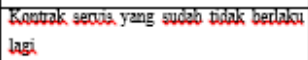 & Sowce & 8 \\
\hline$E_{10}$ & 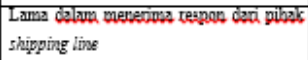 & Source & 7 \\
\hline$E_{1:}$ & Rate container yang gogal & Sowce & 6 \\
\hline$E_{12}$ & Kesulitan mendapetsan containet & Source & 6 \\
\hline$E_{1:}$ & $\begin{array}{l}\text { Rate tidak menentu barend destination } \\
\text { jarang dituin. }\end{array}$ & Sowce & 5 \\
\hline$E_{44}$ & Keterlambatal masulk ke container gate & Deikier & 6 \\
\hline$E_{1 s}$ & 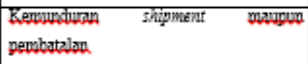 & Deitier & 5 \\
\hline$E_{1 a}$ & Overtime jan bedi & Deivier & 4 \\
\hline$E_{1}$ & 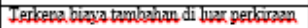 & Return & 6 \\
\hline
\end{tabular}

\begin{tabular}{|c|c|c|c|c|c|c|c|c|}
\hline Kode & Agen Risilko (Risk Agenr) & & & & & & & Oscourar \\
\hline AI & 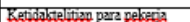 & 81 & 10 & 81 & 9 & 9 & 10 & 9 \\
\hline$A_{2}$ & 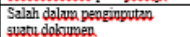 & 5 & 2 & 4 & 7 & 5 & 4 & 4 \\
\hline$A^{3}$ & Jaciogun yes g harang stablo & & & & & & & \\
\hline A4 & 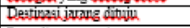 & 3 & 7 & 6 & 5 & 6 & 4 & \\
\hline A5 & $\begin{array}{l}\text { Persedizan container yeng } \\
\text { terbathes }\end{array}$ & 7 & 6 & 6 & 6 & 7 & 7 & 6 \\
\hline A6 & 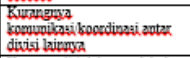 & $|8|$ & 2 & 8 & 7 & 8 & 7 & 8 \\
\hline A7 & $\begin{array}{l}\text { Kuraug teliti dalam, melabicican } \\
\text { proses stuffing }\end{array}$ & 4 & 3 & 5 & 7 & 6 & 6 & 5 \\
\hline As & 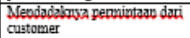 & 8 & 9 & 7 & 8 & 7 & 7 & 8 \\
\hline$A_{9}$ & 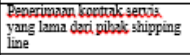 & 8 & 7 & 5 & 8 & 6 & 6 & 7 \\
\hline A10 & 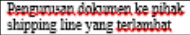 & 5 & 4 & 7 & 7 & 7 & 6 & 6 \\
\hline All & 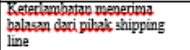 & 8 & 8 & 7 & 10 & 8 & 9 & 8 \\
\hline A.2 & 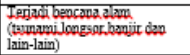 & 1 & 3 & 3 & 3 & 2 & 3 & 2 \\
\hline A13 & 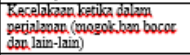 & 7 & 4 & 6 & 4 & 6 & 6 & 5 \\
\hline A14 & $\begin{array}{l}\text { Penambabatar baraug durd } \\
\text { customer }\end{array}$ & 8 & 7 & 8 & 7 & 6 & 5 & 7 \\
\hline A15 & 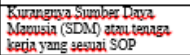 & 6 & 4 & 7 & 6 & 5 & 6 & 6 \\
\hline A16 & 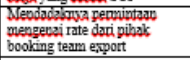 & 7 & 8 & 6 & 8 & 8 & 5 & 7 \\
\hline A17 & 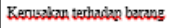 & 3 & 3 & 2 & 2 & 3 & 3 & 3 \\
\hline A18 & $\begin{array}{l}\text { Inquiry teleurat oleh pihalk } \\
\text { shipping live }\end{array}$ & 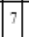 & 6 & 6 & 7 & 6 & 8 & 7 \\
\hline A19 & $\begin{array}{l}\text { Horgan voik dari pihak shipping } \\
\text { line }\end{array}$ & 4 & 7 & 5 & 8 & 7 & 7 & 6 \\
\hline
\end{tabular}

\section{Tabel 4 Tingkat Dampak Kejadian Risiko}

4. Identifikasi Agen Penyebab Risiko

Tabel 5 Identifikasi Agen Penyebab Risiko 
5. Pengukuran nilai peluang kemunculan suatu agen risiko

Tabel 6 Tingkat Probabilitas dari setiap Agen Risiko

\begin{tabular}{|c|c|c|}
\hline Kede & Agen Risilso & $\begin{array}{c}\text { Tinglkat } \\
\text { Probsabilitas }\end{array}$ \\
\hline$A_{1}$ & Ketidalctelition para pelepgia & 9 \\
\hline$A_{2}$ & Salah dalam pengingutan suatu dolamen & 4 \\
\hline$A_{3}$ & Jaingan yang buroug stabl & 6 \\
\hline$A_{4}$ & Destivasijarang dithiph & 5 \\
\hline$A_{4}$ & Persedian container yang terbatas & 6 \\
\hline$A_{6}$ & 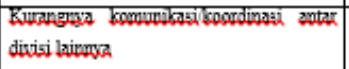 & 8 \\
\hline$A_{7}$ & $\begin{array}{l}\text { Kurang telifi dalum melaculan proses } \\
\text { stuffing }\end{array}$ & 5 \\
\hline$A_{5}$ & Neodacisava penwintase dari customer & 8 \\
\hline$A_{8}$ & $\begin{array}{l}\text { Denerimasan kowtrak secwis yang lama dari } \\
\text { pihak shipping ine }\end{array}$ & ? \\
\hline$A_{10}$ & 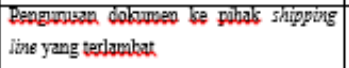 & 6 \\
\hline$A_{11}$ & 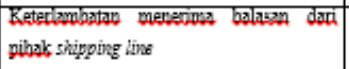 & 8 \\
\hline$A_{12}$ & 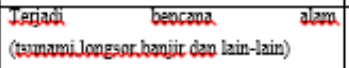 & 2 \\
\hline$A_{13}$ & 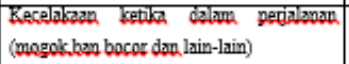 & 5 \\
\hline$A_{i 4}$ & Denawbohan barang decicuctomer & 3 \\
\hline$A_{L S}$ & 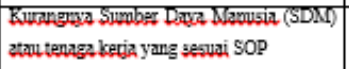 & 6 \\
\hline$A_{16}$ & 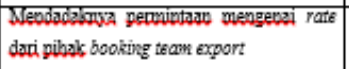 & ? \\
\hline$A_{17}$ & Kenotsalam terhadep berang & 3 \\
\hline$A_{I}$ & Inguiry terdewat oleh prosk shipping line & ? \\
\hline$A_{18}$ & Harga voik dar phalk shipping line & 6 \\
\hline
\end{tabular}

Tabel 7 House of Risk 1

\begin{tabular}{|c|c|c|c|c|c|c|c|c|c|c|c|c|c|c|c|c|c|c|c|c|c|c|}
\hline \multirow[b]{2}{*}{$\begin{array}{l}\text { Business } \\
\text { processes }\end{array}$} & \multirow[b]{2}{*}{ 总昰 } & \multicolumn{20}{|c|}{ Risk Agents } & \multirow{2}{*}{$\begin{array}{c}\text { Severity } \\
\text { of Risk } \\
\text { Events } \\
\text { (Si }\end{array}$} \\
\hline & & $A_{1}$ & $A_{2}$ & As & At & As & $\mathrm{A}_{6}$ & A & A & As & A) & A 10 & $A_{11}$ & An & Ais & $A_{14}$ & $\mathrm{~A}_{15}$ & $A_{16}$ & $A_{17}$ & A 18 & $A_{19}$ & \\
\hline \multirow[t]{2}{*}{ Plan } & $E_{1}$ & & & & & & & & & 9 & & & & & & 9 & & & & & & \\
\hline & $E_{2}$ & & & 9 & & & & & & & & & & & & & & & & & & \\
\hline \multirow[t]{5}{*}{ Make } & Es & & & & & & & & & 3 & & & & & & 9 & & & 9 & & & 5 \\
\hline & $E_{4}$ & & & & & & & & & & 9 & 9 & 3 & & & & & & & & & \\
\hline & $E_{s}$ & 9 & & & & & 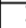 & 1 & & & & & & & & & & & & & & 6 \\
\hline & $\mathrm{E}_{6}$ & & & & & & & & & & & 9 & 3 & & & & & & & & & 6 \\
\hline & $E_{7}$ & & & & & & & & & & & 9 & & & & 3 & & & & & & \\
\hline \multirow[t]{6}{*}{ Source } & $E_{s}$ & & & & & 1 & 7 & 3 & & & & & & & & & & & & & & 8 \\
\hline & Eq & & 1 & & & & & & & & 9 & & 9 & & & & & 1 & & & & 8 \\
\hline & $E_{10}$ & & & & 3 & & & & & & & & & & & & & & & 9 & & \\
\hline & $E_{11}$ & & & & & & & & & & & & & & & & & & & & 9 & 6 \\
\hline & $E_{12}$ & & & & & 3 & & & & 9 & & 9 & & & & & & & & & & 6 \\
\hline & $E_{13}$ & & & & 3 & & & & & & & & & & & & & & & & & 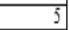 \\
\hline \multirow[t]{3}{*}{ Deliver } & $E_{14}$ & & & & & & & & 3 & & & & & & & & & & & & & 6 \\
\hline & $E_{15}$ & & & & 1 & & & & & & & & & 1 & 9 & & & & & & 3 & \\
\hline & $\mathrm{E}_{16}$ & & & & & & & & 9 & & & & & & & 3 & 3 & & & & & 4 \\
\hline Return & $E_{17}$ & & & & & & & & & & & & & & 9 & & & & & & & 6 \\
\hline \multicolumn{2}{|c|}{ Occurance } & 9 & 4 & 7 & is & 6 & 7 & & 5 & 8 & & 6 & 8 & 2 & 5 & 7 & 6 & 7 & 3 & 7 & 6 & \\
\hline \multicolumn{2}{|c|}{$A R P$} & 486 & 32 & 27 & 205 & 156 & 24 & 27 & 09 & 84 & 945 & 1296 & 888 & 10 & 495 & 882 & 72 & 56 & 135 & 441 & 414 & \\
\hline \multicolumn{2}{|c|}{ Rangking } & & 18 & 10 & 13 & 14 & & 1 & 1 & 2 & 3 & 1 & 4 & \begin{tabular}{|l|}
19 \\
\end{tabular} & 6 & 5 & 16 & 17 & 15 & 8 & 9 & \\
\hline
\end{tabular}

\subsection{House of Risk 2}

1. Menyeleksi agen risiko

Tabel 8 Perhitungan Pareto Agen Risiko

\begin{tabular}{|c|c|c|c|c|c|c|}
\hline $\begin{array}{l}\text { Agen } \\
\text { Risiko }\end{array}$ & Peringkat & ARP & $\begin{array}{c}\text { Kumulatif } \\
\text { ARP }\end{array}$ & \% ARP & $\begin{array}{c}\% \% \\
\text { Kumulatif } \\
\text { ARP }\end{array}$ & Kategori \\
\hline A10 & 1 & 1296 & 1296 & 15.66 & 15.66 & \\
\hline AB & 2 & 984 & 2280 & 11.89 & 27.55 & \\
\hline $\mathrm{A} 9$ & 3 & 945 & 3225 & 11.42 & 38.96 & 4 \\
\hline All & 4 & 888 & 4113 & 10.73 & 49.69 & \\
\hline A14 & 5 & 882 & 4995 & 10.66 & 60.35 & \\
\hline $\mathrm{A} 13$ & 6 & 495 & 5490 & 5.98 & 66.33 & \\
\hline $\mathrm{Al}$ & 7 & 486 & 5976 & 5.87 & 72.20 & \\
\hline A18 & 8 & 441 & 6417 & 5.33 & 77.53 & \\
\hline $\mathrm{A} 19$ & 9 & 414 & 6831 & 5.00 & 82.53 & \\
\hline $\mathrm{A} 3$ & 10 & 270 & 7101 & 3.26 & 85.79 & \\
\hline A7 & 11 & 270 & 7371 & 3.26 & 89.05 & \\
\hline $\mathrm{A} 6$ & 12 & 240 & 7611 & 2.90 & 91.95 & 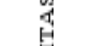 \\
\hline $\mathrm{A} 4$ & 13 & 205 & 7816 & 2.48 & 94.43 & 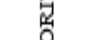 \\
\hline A5 & 14 & 156 & 7972 & 1.88 & 96.32 & $\alpha$ \\
\hline A17 & 15 & 135 & 8107 & 1.63 & 97.95 & \\
\hline A15 & 16 & 72 & 8179 & 0.87 & 98.82 & 8 \\
\hline A16 & 17 & 56 & 8235 & 0.68 & 99.49 & \\
\hline A.28 & 18 & 32 & 8267 & 0.39 & 99.88 & \\
\hline A12 & 19 & 10 & 8277 & 0.12 & 100.00 & \\
\hline
\end{tabular}

2. Mengidentifikasi aksi mitigasi yang relevan Dalam penanganan risiko yang muncul dapat berlaku untuk satu agen atau lebih dari satu agen risiko. Rekomendasi aksi mitigasi dapat dilihat pada tabel di bawah ini :

\section{Tabel 9 Identifikasi Penanganan Risiko}

\begin{tabular}{|l|l|}
\hline \multicolumn{1}{|c|}{ Kode } & \multicolumn{1}{|c|}{ Uraian Penanganan Risiko } \\
\hline PA1 & $\begin{array}{l}\text { Memberikan reward, punishment, dan motivasi kerja kepada seluruh } \\
\text { karyawan }\end{array}$ \\
\hline PA2 & $\begin{array}{l}\text { Menetapkan batas akhir waktu untuk customer mengirimkan data } \\
\text { untuk dokumen ekspor }\end{array}$ \\
\hline PA3 & Membuat checklist harian secara rutin \\
\hline PA4 & Membuat SOP mengenai prosedur pemesanan \\
\hline Kode & Uraian Penanganan Risiko \\
\hline PA5 & $\begin{array}{l}\text { Menetapkan batas waktu kepada customer mengenai permintaan } \\
\text { pemesananan ekspor }\end{array}$ \\
\hline PA6 & Memberikan batas waktu penerimaan kontrak \\
\hline PA8 & Melakukan pengecekan kendaraan sscara berkala \\
\hline PA9 & Melakukan evaluasi secara rutin \\
\hline PA10 & $\begin{array}{l}\text { Membuat kebijakan punishment yang tidak melakukan pekerjaan } \\
\text { sesuai SOP }\end{array}$ \\
\hline PA11 & Memberikan lingkungan keria yang nyaman bagi para pekerja \\
\hline
\end{tabular}


3. Mengukur nilai korelasi agen risiko dengan strategi penanganan risiko

Tabel 10 Nilai Korelasi Risk Agents dengan Strategi Penanganan

\begin{tabular}{|c|c|c|c|c|c|c|c|c|c|c|c|}
\hline \multirow{2}{*}{ RiskAgent } & \multicolumn{11}{|c|}{ Preventive Action } \\
\hline & PA & $P A$ & $P A$ & $\mathrm{PA}$ & PAs & $\mathrm{PA}_{0}$ & P. & PAs & P.A & PAin & PAin \\
\hline din & 9 & 9 & 9 & & & & & & & & \\
\hline As & & & & 9 & 9 & & & & & & \\
\hline do & & & & & & 9 & 3 & & & & \\
\hline dif & & & & & & 9 & 3 & & & & \\
\hline dis & & & & 3 & 9 & & & & & & \\
\hline$d u$ & & & & & & & & 9 & & & \\
\hline$d$ & & & 9 & & & & & & 9 & 3 & 9 \\
\hline dis & & & & & & & 9 & & & & \\
\hline
\end{tabular}

4. Mencari nilai total efektivitas

Setelah mencari nilai korelasi, maka langkah selanjutnya mengkalkulasi atau mencari nilai total efektivitas $\left(T E_{k}\right)$ dengan formula sebagai berikut :

Keterangan :

$$
T E_{k}=\sum A R P_{j} E_{j k}
$$

$T E_{k}=$ Total efektivitas

$A R P j=$ Prioritas risiko (risk priority index)

$E j k=$ Nilai korelasi antara suatu agen risiko dengan penanganan risiko

Tabel 11 Total Efektivitas Tindakan Penanganan Risiko

\begin{tabular}{|c|l|c|}
\hline Kode & \multicolumn{1}{|c|}{ Uraian Penanganan Risiko } & $\begin{array}{c}\text { Total Efektivitas } \\
\text { (TEk) }\end{array}$ \\
\hline PA1 & $\begin{array}{l}\text { Memberikan reward, punishment, dan motivasi } \\
\text { kerja kepada seluruh karyawan }\end{array}$ & 11,664 \\
\hline PA2 & $\begin{array}{l}\text { Menetapkan batas akhir waktu untuk customer } \\
\text { mengirimkan data untuk dokumen ekspor }\end{array}$ & 11,664 \\
\hline PA3 & Membuat checklist harian secara rutin & 16,038 \\
\hline PA4 & Membuat SOP mengenai prosedur pemesanan & 11,502 \\
\hline PA5 & $\begin{array}{l}\text { Menetapkan batas waktu kepada customer mengenai } \\
\text { permintaan pemesananan ekspor }\end{array}$ & 16,794 \\
\hline PA6 & Memberikan batas waktu penerimaan kontrak & 16,497 \\
\hline PA7 & Memfollow up secara rutin ke pihak shipping line & 9,468 \\
\hline PA8 & Melakukan pengecekan kendaraan s5cara berkala & 4,455 \\
\hline PA9 & Melakukan evaluasi secara rutin & 4,374 \\
\hline PA10 & $\begin{array}{l}\text { Membuat kebijakan punishment yang tidak } \\
\text { melakukan pekerjaan sesuai SOP }\end{array}$ & 1,458 \\
\hline PA11 & $\begin{array}{l}\text { Memberikan lingkungan kerja yang nyaman bagi } \\
\text { para pekerja }\end{array}$ & 4,374 \\
\hline
\end{tabular}

5. Mengukur tingkat kesulitan

Merupakan upaya mereduksi kemunculan agen risiko, dimana skala tingkat kesulitan dalam penerapan aksi mitigasi.
Tabel 12 Tingkat Kesulitan dari Tindakan Pencegahan Risiko

\begin{tabular}{|l|l|c|}
\hline Kode & \multicolumn{1}{|c|}{ Uraian Penanganan Risiko } & $\begin{array}{c}\text { Tingkat } \\
\text { Kesulitan }\end{array}$ \\
\hline PA1 & $\begin{array}{l}\text { Memberikan reward, punishment, dan motivasi kerja kepada } \\
\text { seluruh karyawan }\end{array}$ & 4 \\
\hline PA2 & $\begin{array}{l}\text { Menetapkan batas akhir walktu untuk customer mengirimkan } \\
\text { data untuk dokumen ekspor }\end{array}$ & 5 \\
\hline PA3 & Membuat checklist harian secara rutin & 4 \\
\hline PA4 & Membuat SOP mengenai prosedur pemesanan & 3 \\
\hline PA5 & $\begin{array}{l}\text { Menetapkan batas waktu kepada customer mengenai } \\
\text { permintaan pemesananan ekspor }\end{array}$ & 5 \\
\hline PA6 & Memberikan batas waktu penerimaan kontrak & 5 \\
\hline PA7 & Memfollow up secara rutin ke pihak shipping line & 3 \\
\hline PA8 & Melakukan pengecekan kendaraan sscara berkala & 4 \\
\hline PA9 & Melakukan evaluasi secara rutin & 4 \\
\hline PA10 & $\begin{array}{l}\text { Membuat kebijakan punishment yang tidak melakukan } \\
\text { pekerjaan sesuai SOP }\end{array}$ & 4 \\
\hline PA11 & Memberikan lingkungan kerja yang nyaman bagi para pekerja & 4 \\
\hline
\end{tabular}

6. Mengkalkulasi Total Efektivitas

Tabel 13 Total Efektivitas

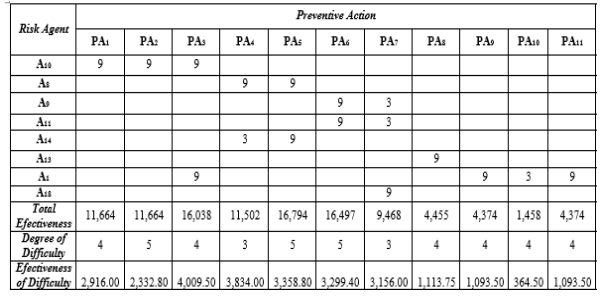

Tabel 14 House of Risk 2

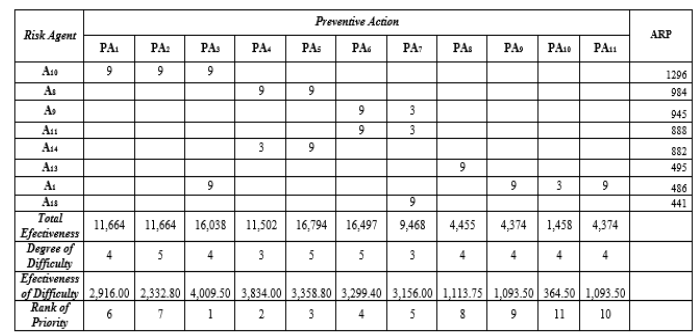

\section{Analisis dan Pembahasan}

Berdasarkan pengamatan yang peneliti lakukan, diperoleh data total keterlambatan shipment dan data total keterlambatan stuffing dimana selanjutnya dilakukan pengolahan data menggunakan metode House of Risk (HOR) untuk mengetahui apa saja kejadian risiko yang terjadi, mengetahui apa saja agen penyebab risiko serta mengetahui strategi penanganan untuk meminimalisir penyebab risiko kategori prioritas.

Dari hasil pengolahan data dan analisis menggunakan metode House of Risk dimana ada 2 tahapan yaitu HOR fase 1 dimana didapatkan 17 kejadian risiko dan 19 agen penyebab risiko yang didapatkan berdasarkan hasil dari 6 responden yang berkaitan erat dalam pengiriman ekspor dimana hasil akhir dari HOR 1 untuk mengetahui indeks prioritas yang menjadi bahan pertimbangan dalam menentukan 
prioritas penanganan risiko. HOR 1 yang memiliki indeks prioritas tertinggi salah satunya yaitu pengurusan dokumen ke pihak shipping line yang terlambat (A10), mendadaknya permintaan dari customer (A8), penerimaan kontrak servis yang lama dari pihak shipping line (A9), keterlambatan menerima balasan dari pihak shipping line (A11), penambahan barang dari customer (A14), kecelakaan ketika dalam perjalanan (mogok,ban bocor dan lainlain) (A13), ketidaktelitian para pekerja (A1), inquiry terlewat oleh pihak shipping line (A18), harga naik dari pihak shipping line (A19), jaringan kurang stabil (A3) dan kurang teliti dalam melakukan proses stuffing (A7).

Kemudian dari hasil agen penyebab risiko yang memiliki indeks prioritas tertinggi - terendah, selanjutnya di analisis di HOR fase 2 yang akan dilakukan seleksi agen penyebab risiko dengan menggunakan analisa pareto untuk mengetahui agen risiko yang termasuk kategori prioritas maupun non prioritas. Sehingga terdapat 8 agen penyebab risiko yang termasuk kategori prioritas dan 11 agen risiko yang termasuk kategori non prioritas. Tabel hasil agen penyebab risiko yang memiliki ARP tertinggiterendah dapat dilihat pada tabel 8 .

Kategori prioritas yang telah dijelaskan di atas, didapatkan beberapa strategi penanganan berdasarkan jawaban dari 6 responden. Terdapat 11 strategi penanganan dimana strategi penanganan tersebut akan dilakukan nilai korelasi atau hubungan strategi dengan agen risiko, tingkat kesulitan dalam penerapan strategi penanganan, serta strategi penanganan berdasarkan nilai ETD tertinggi. Berikut hasil dari analisa HOR 2 berdasarkan nilai ETD tertinggi yaitu :

\section{Tabel 15 Hasil Analisa HOR 2 Berdasarkan Nilai} ETD Tertinggi

\begin{tabular}{|c|c|c|c|}
\hline Kode & Aksi mitigasi & Peringkat & ETD \\
\hline PA3 & Membuat checklist harian secara rutin & 1 & $4,009.50$ \\
\hline PA4 & $\begin{array}{l}\text { Membuat SOP mengenai prosedur } \\
\text { pemesanan }\end{array}$ & 2 & $3,834.00$ \\
\hline PA5 & $\begin{array}{l}\text { Menetapkan batas waktu kepada } \\
\text { customer mengenai permintaan } \\
\text { pemesananan ekspor }\end{array}$ & 3 & $3,358.80$ \\
\hline PA6 & $\begin{array}{l}\text { Memberikan batas waktu penerimaan } \\
\text { kontrak }\end{array}$ & 4 & $3,299.40$ \\
\hline PA7 & $\begin{array}{l}\text { Memfollow up gecara rutin ke pihak } \\
\text { shipping line }\end{array}$ & 5 & $3,156.00$ \\
\hline PAl & $\begin{array}{l}\text { Memberikan reward, punishment, } \\
\text { dan motivasi kerja kepada seluruh } \\
\text { karyawan }\end{array}$ & 6 & $2,916.00$ \\
\hline$\overline{\mathrm{PA} 2}$ & $\begin{array}{l}\text { Menetapkan batas alkhir waltu untuk } \\
\text { customer mengirimkan data untuk } \\
\text { dokumen ekspor }\end{array}$ & 7 & $2,332.80$ \\
\hline PAB & $\begin{array}{l}\text { Melakukan pengecelan kendaraan } \\
\text { secara berkala }\end{array}$ & 8 & $1,113.75$ \\
\hline PA9 & Melakukan evaluasi secara rutin & 9 & $1,093.50$ \\
\hline PA11 & $\begin{array}{l}\text { Memberikan lingkungan kerja yang } \\
\text { nyaman bagi para pekerja }\end{array}$ & 10 & $1,093.50$ \\
\hline PA10 & $\begin{array}{l}\text { Membuat kebijakan punishment yang } \\
\text { tidak melakukan pekerjaan sesuai } \\
\text { SOP }\end{array}$ & 11 & 364.50 \\
\hline
\end{tabular}

\section{KESIMPULAN}

1. Berdasarkan hasil penelitian yang telah dilakukan dengan menggunakan metode House of Risk ditemukan 17 kejadian risiko (risk events) berdasarkan dari 6 responden untuk lembar survei pengidentifikasian kejadian risiko pada PT Agility International dapat dilihat pada lampiran A. Berikut tabel identifikasi kejadian risiko sebagai berikut :

\begin{tabular}{|l|l|}
\hline$K_{0}$ & \multicolumn{1}{|c|}{ Kejadian Risiko } \\
\hline$E_{1}$ & Perubahan jadwal untuk kegiatan atau proses stuffing \\
\hline$E_{2}$ & Sistem IT mengalami trouble \\
\hline$E_{9}$ & $\begin{array}{l}\text { Terlambat untuk melakukan proses stuffing sehingga waktu storage lebih } \\
\text { lama }\end{array}$ \\
\hline$E_{4}$ & Terlambat melakukan proses booking space \\
\hline$E_{5}$ & Kesalahan staff dalam melakukan proses stuffing \\
\hline$E_{6}$ & Full booking space \\
\hline$E_{7}$ & Penumpukan barang di gudang \\
\hline$E_{8}$ & Container ditolak karena tidak layak pakai \\
\hline$E_{9}$ & Kontrak servis yang sudah tidak berlaku lagi \\
\hline$E_{10}$ & Lama dalam menerima respon dari pihak shipping line \\
\hline$E_{11}$ & Rate container yang gagal \\
\hline$E_{11}$ & Kesulitan mendapatkan container \\
\hline$E_{13}$ & Rate tidak menentu karena destination jarang dituju \\
\hline$E_{14}$ & Keterlambatan masuk ke container gate \\
\hline$E_{15}$ & Kemunduran shipment maupun pembatalan \\
\hline$E_{16}$ & Overtime jam kerja \\
\hline$E_{17}$ & Terkena biaya tambahan di luar perkiraan \\
\hline
\end{tabular}

2. Terdapat 19 agen risiko yang menjadi output untuk HOR fase 1 agen risiko prioritas diantaranya, ketidaktelitian para pekerja (A1), salah dalam penginputan suatu dokumen (A2), jaringan kurang stabil (A3), destinasi jarang dituju (A4), persediaan container yang terbatas (A5), kurangnya komunikasi/koordinasi antar divisi lainnya (A6), kurang teliti dalam melakukan proses stuffing (A7), mendadaknya permintaan dari customer (A8), penerimaan kontrak servis yang lama dari pihak shipping line (A9), pengurusan dokumen ke pihak shipping line yang terlambat (A10), keterlambatan menerima balasan dari pihak shipping line (A11), terjadi bencana alam (tsunami, longsor, banjir dan lainlain) (A12), kecelakaan ketika dalam perjalanan (mogok,ban bocor dan lain-lain) (A13), penambahan barang dari customer (A14), kurangnya Sumber Daya Manusia (SDM) atau tenaga kerja yang sesuai SOP (A15), mendadaknya permintaan mengenai rate dari pihak booking team export (A16), kerusakan terhadap barang (A17), inquiry terlewat oleh pihak shipping line (A18), harga naik dari pihak shipping line (A19).

3. Strategi penanganan yang akan dilakukan PT Agility International dalam menangani risiko yang memiliki kategori prioritas sebanyak 11 aksi. Berikut tabel uraian penanganan risiko: 


\begin{tabular}{|l|l|}
\hline Kode & \multicolumn{1}{|c|}{ Uraian Penanganan Risiko } \\
\hline PA1 & $\begin{array}{l}\text { Memberikan reward, punishment, dan motivasi kerja kepada seluruh } \\
\text { karyawan }\end{array}$ \\
\hline PA2 & $\begin{array}{l}\text { Menetapkan batas alchir waktu untuk customer mengirimkan data untulk } \\
\text { dokumen ekspor }\end{array}$ \\
\hline PA3 & Membuat checklist harian secara rutin \\
\hline PA4 & Membuat SOP mengenai prosedur pemesanan \\
\hline PA5 & $\begin{array}{l}\text { Menetapkan batas waktu kepada customer mengenai permintaan } \\
\text { pemesananan ekspor }\end{array}$ \\
\hline PA6 & Memberikan batas waktu penerimaan kontrak \\
\hline PA7 & Memfollow up secara rutin ke pihak shipping line \\
\hline PA8 & Melakukan pengecekan kendaraan sscara berkala \\
\hline PA9 & Melakukan evaluasi secara rutin \\
\hline PA10 & $\begin{array}{l}\text { Membuat kebijakan punishment yang tidak melakukan pekerjaan sesuai } \\
\text { SOP }\end{array}$ \\
\hline PA11 & Memberikan lingkungan kerja yang nyaman bagi para pekerja \\
\hline
\end{tabular}

\section{REFERENSI}

Amelia, P., Vanany, I., \& Indarso. (2017). Analisis Risiko Operasional Pada Divisi Kapal Perang PT. PAL Indonesia Dengan Metode House Of Risk. Jurnal Sistem Informasi Indonesia, 2(1).

Capt. R.P Suyono, M. (2007). Shipping: Pengangkutan Intermodal Ekspor Impor Melalui Laut. Jakarta: PPM.

Darmawi, H. (2016). Manajemen Risiko Edisi 2,Cet.1. Jakarta : Bumi Aksara.

Fahmi, I. (2010). Manajemen Risiko: Teori, Kasus dan Solusi . Bandung: Alfabeta.

Hanafi, M. M. (2016). Manajemen Risiko. Yogyakarta: UPP STIM YKPN.

Irawan, H. T., Pamungkas, I., \& Muzakir. (2019 ). Analisis Risiko Rantai Pasok Komoditas Cengkeh di kecamatan Salang Kabupaten Simelue . Jurnal Optimalisasi, Vol 5.

Kusnindah, C., Sumantri, Y., \& Yuniarti, R. (2014). PENGELOLAAN RISIKO PADA SUPPLY CHAIN DENGAN MENGGUNAKAN METODE HOUSE OF RISK (HOR) (Studi Kasus di PT. XYZ). Jurnal Rekayasa dan Manajemen Sistem Industri, 2(3), p661-671.

Lutfi, A., \& Irawan, H. (2012). Analisis Risiko Rantai Pasok dengan Model House of Risk (Studi Kasus Pada PT XXX). Jurnal Manajemen Indonesia.

Magdalena, R., \& Vannie. (2019). ANALISIS RISIKO SUPPLY CHAIN DENGAN MODEL HOUSE OF RISK (HOR) PADA PT TATALOGAM LESTARI. J@ti Undip: Jurnal Teknik Industri, Vol. 14, No. 2.

Nyoman Pujawan, M. (2017). Supply Chain Management Edisi Ke 3. Yogyakarta: Andi.

Rabbani, L. S. (2019). Analisis Risiko Penumpukan Barang di Pelabuhan Selama Proses Pengiriman Muatan Jenis Wirerod dengan Metode House of Risk (HOR),Tugas Akhir.

Rizqiah, E. (2017). Manajemen Risiko Supply Chain Dengan Mempertimbangkan Kepentingan Stakeholder Pada Industri Gula (Doctoral dissertation, Institut Teknologi Sepuluh Nopember). 38-45.

Sutawijaya , \& Marlapa. (2016). Supply Chain Management: Analisis dan Penerapan Menggunakan Reference (SCOR) Di PT Indoturbine. Jurnal Ilmiah Manajemen, 121138.

Tandjung, M. (2010). Aspek dan Prosedur Ekspor Impor. Jakarta: Salemba Empat.

Tang, C. S. (2005). Perspectives in Supply Chain Risk Management: A Review. International Journal of Production Economics . 